\title{
Mutliple Use: \\ Improving on a Good Idea, and Avoiding a Red Herring
}

\author{
by
}

Henry H. Webster and Jan J. Hacker ${ }^{1}$

\begin{abstract}
For purposes of management, forest land should be divided into three categories: areas to be managed primarily for natural values, areas to be managed primarily for developed recreation and areas where intensive vegetation management will be concentrated. Major changes in land tenure are substantially an energy sink that consume large amounts of effort while producing little useful result.
\end{abstract}

\section{Résumé}

A des fins d'aménagement, les terrains forestiers devraient être divisés en trois catégories : les zones à être aménagées principalement pour leurs richesses naturelles, les zones à être aménagées principalement pour des fins de récréation structurée, et les zones où un aménagement intensif de la végétation sera concentré. Les changements importants dans la gestion des terres sont en sommes des siphons qui aspirent de grande quantité d'énergie tout en donnant que de maigres résultats.

\section{Introduction}

Roy Strang discussed important ideas in the April 1983 issue of The Forestry Chronicle. He wrote under the eyecatching title "Multiple Use and Muddled Thinking". One of his points was that forest resource managers need to better separate conflicting uses of forest land. He suggested that areas to be intensively managed for timber be more definitively separated from areas to be managed primarily for other important forest values, and added that productive capacity of land to grow timber would be an important factor in making such separation.

Two months later Anthony Stout (1983) made somewhat related arguments in the Journal of Forestry. He also proposed more definitive separation of conflicting uses, and then went further to suggest major institutional change in land tenure arrangements. In the US context, he suggested that public land primarily valuable for growth and harvest of timber be shifted from direct public-agency management to a variety of lease arrangements with timber industry firms. Generally similar arguments were also advanced at about the same time by Nelson (1982). These arguments for major change in land tenure arrangements were generically part of the "privatizaiton" discussion that has occured in the United States during the past several years.

We write to do two things. The first is to build on Strang's important points concerning need for better separation of conflicting uses. In doing this we shall draw upon ideas

\footnotetext{
1The authors are members of Michigan Department of Natural Resources. Henry H. Webster is State Forester. Jan J. Hacker is analyst in the Office of the Great Lakes.
}

suggested by Marion Clawson some time ago. We shall also outline efforts to apply these ideas in management of stateowned public forest land in Michigan. Second, we shall argue that proposals for major institutional change in land tenure arrangements seem regularly to come to little or nothing while using up a great deal of human energy. This point can be illustrated at both national and provincial or state levels.

We believe that these major points (concerning the importance of separating conflicting uses, and the substantial futility of proposed land tenure changes) are applicable throughout North America. Admittedly, our examples are drawn primarily from the United States - that for reasons of specific knowledge in adequate depth. We shall particularly value discussion from Canadian forest managers that either confirm or amend our belief that these points are broadly applicable in North America.

\section{Better Separation of Conflicting Uses: Improving on Strang's Idea}

Multiple use evolved as a concept from two separate but entangled arguments. Forestry in North America once had an almost wholly custodial orientation. Primary emphasis was on timber to the extent there was any real emphasis on explicit outputs. (By contrast, forestry in western Europe earlier had its origin in game production and hunting, particularly by major landowners.) As other values became important, there was an extensive discussion of the legitimacy of multiple-use and the manner in which it was to be applied. The somewhat accidental outcome of a part of this discussion is still at the root of present difficulties. 
One notable part of this discussion occurred in the early 1940's with Samuel T. Dana (1943) and G.A. Pearson (1944) as protagonists. The argument was about two separate questions: (1) should water, recreation, and wildlife be considered equal to timber as products of forests; and (2) should multiple-use be applied on a small-area basis with several uses closely intermixed and all treated with equal priority, or should multiple-use be applied on a larger-area basis with primary purposes of management designated for particular land units within this larger pattern? Sam Dana argued that water, recreation, and wildife are as important as timber, and that a small-area equal-priority approach to multiple use should be taken. Gus Pearson argued that timber should be pre-eminent, and that a larger-area approach should be taken with primary purposes designated. (Pearson's argument included an example posed in terms of a well-organized farm yard, an example that is a beautiful illustration of effective expository writing.)

Somehow ensuing discussion, legislation and action lost sight of the fact that two separate questions were involved. Events won the day for Dana's viewpoint that water, recreation, and wildlife are as important as timber, which makes sense to these observers, but somehow the second question concerning the size of units and possible designation of primary purposes was submerged. The effect was to decide in favor of the small-area approach without ever really considering the second question on its separate merits.

The result has been a long period of emerging and intensifying difficulties. They have taken several forms. Endless case-by-case argument about land-use designations is one manifestation: e.g. each wilderness proposal has to be argued as if life itself depends on the outcome since there is no explicit and positive link to other purposes of forest management elsewhere. Another manifestation is substantial problems of insecurity of timber management investments. Where should investments be made in intensive timber management when no one really knows where it will or will not be possible to harvest?

Some very modest progress toward clarification was made in the late 1960's and early 1970's. The recommendations of the US Public Land Law Review Commission were one case in point. Three separate recommendations called for an improved system of classifying US public land, for prompt identification of major scenic and natural assets of public land, and for designation of areas where timber is to be the primary value. Timber-growing investments were to be concentrated on these latter areas where timber production was to be the "dominant use". The whole idea subsequently blew-up when the recommendations were quite erroneously intepreted by some as calling for timber to be the dominant use on all US public land. Despite this unfortunate misinterpretation (and highly adverse public reaction), the seed was planted - better separation of otherwise conflicting uses is needed.

The next major contribution was made by Marion Clawson (1974, 1975). He analyzed complementary compatible and conflicting uses of forest resources. He pointed out that uses that may be complementary or compatible at low intensity may conflict seriously when pushed more strongly. In this context, he pointed out three sets of values that conflict seriously when strongly pushed on the same land: wilderness, highly developed recreation, and highly intenstive timber growth/harvest and habitat management. This struck a goodly number of forest managers as right on target: we simply know that, we've been there! Thus
Clawson's analysis entirely supports Roy Strang's suggestion with one improvement. There are three rather than two major uses of forest land that need to be separated more precisely if each of these uses is to be effectively pursued.

Michigan is attempting to apply this idea in managing its 3.8-million-acre (1.54 MM ha) State Forest system. The general policy under which this system is managed calls for designating primary and secondary purposes of management where needed to separate conflicting uses. The focus is essentially on the three major uses identified by Clawson: areas to be managed primarily for natural values, areas to be managed primarly for developed recreation, and areas devoted to intensive vegetation management for timber and wildlife. Where one use has been designated as primary, management will be focussed on it. Secondary uses will be encouraged only to the point where they begin to affect the primary purpose of management. This system is being put into effect via preparation of a comprehensive management plan for each of the six State Forests. These plans are being prepared on an interdisciplinary basis within the framework of a statewide forest resources plan. This plan provides major direction by establishing output targets for all major forest values. A reorganization of the State Forest system also prepared the way for this approach. Thirty-three small State Forests averaging 115000 acres (46.6 M ha) were combined into six large State Forests averaging 630000 acres (255.1 $\mathrm{M} \mathrm{ha}$ ). This was done to focus planning at a scale more conducive to separation of conflicting uses. Thus Roy Strang's idea is a good one if improved via Marion Clawson's three-way categorization of forest uses. Attempts are being made to apply this idea.

\section{Proposed Major Change In Land Tenure: A Red Herring}

Proposals for major change in land tenure arrangements have a history of frustration. For example, during the 1980's in the United States there has been a loudly heralded effort toward "privatization" of federally owned and managed forest and range land. This "privatization" was strongly advocated by a national administration that was swept into office by a substantial electoral majority. Apparently many advocating privatization strongly believed that private management is a priori more effective and efficient than public management. Privatization proposals were also rooted to some degree in the so-called Sagebrush Rebellion, a fairly widespread expression of Western disaffection that occurred in the late 1970 's and early 1980's. Somewhat parallel discussion of possible privatization of state-owned forest land occurred in Michigan at approximately the same time or a bit later. Here the apparent driving force was an assumption that public ownership had a negative effect on economic development, particularly in an economically depressed and extensively forested portion of the state.

These efforts toward privatization in the United States have now essentially collapsed. Very few acres of federally owned forest and range land have actually been sold. The socalled Asset Management Program was rather promptly called off by Donald Hodel when he became Secretary of the Interior in 1984. This collapse was accelerated by the opposition of several western state governors to privatization (this despite earlier Sagebrush Rebellion statements). It was also aided by timber industries firms' evident lack of interest in purchasing large areas of previously public land. Indeed at the time many of these firms were attempting to "monetize" forest land they already owned. They simply couldn't afford more 
land; they needed to convert some they already held into cash to cover cash-flow difficulties. (Chris Leman [1985] has analyzed this collapse of privatization in additional and interesting detail.)

In Michigan a Public Lands Task Force appointed by the Governor came to a similar conclusion. It strongly recommended against any sizeable net reduction in public forest acreage by sale. It also strongly recommended against large scale leasing of land that is now directly managed by state agencies. Indeed its preference for the status quo in land tenure arrangements went further; it also recommended against a very modest proposal for experimental timber volume agreements designed to encourage new or expanded timber industries in carefully selected areas of readily apparent timber surplus. It opted for simple continuation of present management and timber sale arrangements despite recommendations for modest change by the principal managing agency.

Ontario to the best of our limited knowledge has also had difficulties making changes in land tenure arrangements. As we understand, there has been a longstanding question as to responsibility for regeneration and other aspects of silvicultural management on Crown land. Over several decades, attempts have been made to resolve the question in several quite different manners. For example, the Ontario Crown Timber Act of 1954 assigned responsibility for management to the firm holding the license for a given area of publicly-owned forest land. This arrangement was reversed in the early 1960's. Amendment to the Crown Timber Act in 1962 assigned responsibility for all management of Crown lands to the province (specifically to the then Minister of Lands and Forests). More recently there has been a further change, with the firm holding the license again responsible for carrying out silvicultural management, aided by considerable public financial aid provided by the province. Again to our understanding, each firm is linked with the Ministry of Natural Resources by a specific forest management agreement. (These latest changes affect detailed responsibilities implicit in tenure arrangements, but not in basic land management and ownership arrangements.)

Hopefully, this latest arrangement will prove satisfactory for effective silvicultural management. But in any case, the several changes and reversals do illustrate the difficulty of making changes in land tenure arrangements that really accomplish something. The current arrangement via forest management agreements could perhaps be interpreted as a turn away from changing tenure arrangements, and a turn toward a focus on funding for silvicultural management. It seems that funding or lack of it always has been the important issue - and is now being addressed more directly.

\section{Some Possible Conclusions}

Simultaneous appearance of articles by Strang and Stout was a happenstance. Nevertheless their arguments provide opportunity to reach three simple but important conclusions.

First, we need to advance beyond general multiple use. That is necessary to focus resource management efforts more effectively, and particularly to separate conflicting uses of forest resources in a more productive manner. The alternative is a continuation of aimless and endless conflict.

Second, there are three (not two) major categories of uses to be separated: areas to be managed primarily for naturalistic values, areas to be managed primarily for developed recreation, and areas where intensive vegetation management will be concentrated. Foresters can - indeed should - productively support better separation of this sort.

Third, major change in land tenure arrangements is substantially an energy sink. Large amounts of effort seem to regularly produce little or no useful result. Proposals for major tenure change frequently produce granitic deadlock. There may be situations where tenure arrangements are so badly out of order as to require major tenure change. But proposals for such change more frequently function as a red herring. They frequently divert attention away from productive approaches that could improve resource management within existing tenure arrangements. We are tempted to agree with the old saying: don't fix it if it isn't really broke, otherwise it may well be broke.

\section{References}

Clawson, Marion. 1974. Forest Policy: Conflict, Compromises, Consensus. Resources for the Future Working Paper $L W-1$. Washington, D.C. $360 \mathrm{p}$.

Clawson, Marion. 1975. Forests for Whom and for What. John Hopkins University Press. $175 \mathrm{p}$.

Dana, Samuel T. 1943. Multiple use, biology, and economics. Journal of Forestry 41.625-626.

Leman, Christopher K. 1985. How the privatization revolution failed, and why public land management needs reform anyway. In Francis, J. and Ganzel, R. (ed). Western Public Lands. Roman and Allanheid Publishers. $255 \mathrm{p}$

Nelson, Robert H. 1982. The public lands. In Portney, Paul R. (ed). Current Issues in Natural Resource Policy. John Hopkins University Press. $300 p$

Pearson, G.A. 1944. Multiple use in forestry. Journal of Forestry 42: 243-249.

Stout, Anthony T. 1983. Multiple use doesn't work in the field. Journal of Forestry 81: 417 .

Strang, R.M. 1983. Multiple use and muddled thinking. Forestry Chronicle. 59: 50-51.

\section{Cruising Anecdotes Sought}

Most foresters have had some experience cruising. If you have any amusing stories on this topic to share, we'd like to hear them! Keep tuned.

Send to

Henrik Deichmann, Party Chief for "Cruising Anecdotes"

c/o Terra Nova National Park,

Glovertown, NEWFOUNDLAND AOG 2 LO

Phone (709) 533-2801 or 533-6799 